 \\ UF| $\mid$ FLORERIDA \\ IFAS Extension
}

\section{Keeping it Safe: Space Heaters ${ }^{1}$}

Mary N. Harrison ${ }^{2}$

Each year, hundreds of people go to hospital emergency rooms because of injuries related to space heaters. When clothing comes in contact with a heating element or flame it can catch fire. Leaking gas can cause explosions. Inhaling carbon monoxide from a malfunctioning, poorly vented, or unvented gas heater can cause death.

\section{General Safety Tips for All Space Heaters}

1. Read the label and follow the instructions for installation and operation.

2. Keep paper, clothing, furniture, and especially children away from space heaters.

3. Keep the heater in safe working condition. Replace any missing grille, guard, or controls at once.

\section{Safety Tips for Electric Space Heaters}

1. Free-standing electric heaters should have tip-over switches. These switches shut off the current if the unit is knocked over. This helps prevent a fire if the heater falls against fabric or other flammable materials.
2. There must be a guard around the heating coil of your heater. A wire grille or other protection is essential to keep fingers or fabrics from touching the hot coil.

3. If you must use an extension cord, make sure it's marked with a power rating at least as high as that on the label of the heater itself.

4. Keep it away from water! Don't use a portable electric heater anywhere in a bathroom or near a sink.

\section{Safety Tips for Gas Space Heaters}

1. Your gas space heater should be properly vented. The vent pipe should have no cracks through which deadly carbon monoxide might leak. An undersized or clogged vent is very hazardous.

2. If you must use an unvented heater, keep a door or window slightly open at all times. Good ventilation during use is crucial!

3. Light the match before you turn on the gas, to prevent accumulation of gas. This will prevent gas from flaring up when you bring the match near.

1. This document is FCS5233-02, one of a series of the Department of Family, Youth and Community Sciences, Florida Cooperative Extension Service, Institute of Food and Agriculture Sciences, University of Florida. Publication: May 2002. Revised: December 2005. Please visit the EDIS Web site at http://edis.ifas.ufl.edu

2. Mary N. Harrison, professor, Department of Family, Youth and Community Sciences, Cooperative Extension Service, Institute of Food and Agricultural Sciences, University of Florida, Gainesville, 32611.

The Institute of Food and Agricultural Sciences (IFAS) is an Equal Opportunity Institution authorized to provide research, educational information and other services only to individuals and institutions that function with non-discrimination with respect to race, creed, color, religion, age, disability, sex, sexual orientation, marital status, national origin, political opinions or affiliations. U.S. Department of Agriculture, Cooperative Extension Service, University of Florida, IFAS, Florida A. \& M. University Cooperative Extension Program, and Boards of County Commissioners Cooperating. Larry Arrington, Dean 
4. Remember that a space heater can ignite flammable liquids and vapors. Never use a space heater in the same room where gasoline is stored. Never use a space heater where paint thinners, kerosene, or other volatile liquids are being used.

\section{Safety Tips for Kerosene-, Oil-, or Wood-burning Space Heaters}

1. These should be properly vented to prevent the accumulation of carbon monoxide.

2. Use only the fuel for which the heater was designed. Don't use kerosene in an oil heater and vice versa.

Never use highly flammable liquids--like gasoline--to get a wood stove started. 